\title{
PELATIHAN DAN PENDAMPINGAN HOME INDUSTRI KELOMPOK PKK DESA FAJAR BARU: PEMBUATAN DETERGEN CAIR
}

\author{
Agung Abadi Kiswnadono ${ }^{1 *}$, Nurhasanah ${ }^{1}$, Jamiatul Akmal ${ }^{2}$ \\ 1) Jurusan Kimia FMIPA Universitas Lampung, Bandar Lampung \\ Jl. Prof. Sumantri Brojonegoro No.1 Bandar Lampung 35145 \\ 2) Jurusan Teknik Mesin, Fakultas Teknik Universitas Lampung, Bandar Lampung \\ Jl. Prof. Sumantri Brojonegoro No.1 Bandar Lampung 35145 \\ agung.abadi@fmipa.unila.ac.id
}

\begin{abstract}
ABSTRAK
Desa Fajar Baru Kecamatan Jati Agung walaupun bukan sebagai daerah pusat industri, tetapi Desa ini mempunyai akses yang strategis dengan lembaga pendidikan dan pusat bisnis. Kedekatan dengan lembaga pendidikan SLTA, PTN maupun PTS serta dengan pusat bisnis, yakni pasar tradisional, minimarket dan kuliner malam memberikan peluang kepada masyarakat untuk meningkatkan wirusaha, yakni menjadi produsen, penyalur, pedagang, ataupun grosir. Salah satu kegiatan yang dapat diusahakan adalah grosir bahan baku Loundry seperti detergen. Walaupun produk ini mudah didapat, tetapi bagi konsumen akan merasa sulit untuk mendapatkan produk tersebut dengan harga yang lebih murah. Pembuatan detergen merupakan salah satu produk yang berpotensi dijadikan sebagai kegiatan Home Industry. Bahan detergen adalah produk yang mudah dibuat dengan modal yang murah. Tujuan dari kegiatan pengabdian kepada masyarakat ini adalah, selain pendampingan dalam pembuatan detergen, juga pendampingan kepada kelompok mitra dalam bentuk pelatihan, workshop dan praktek serta pengenalan mesin pembuat detergen, sehingga dihasilkan produk dengan harga terjangkau oleh masyarakat (murah) dan pada akhirnya dapat mengantisipasi keinginan segementasi pasar. Hasil pengabdian didaptkan bahwa peningkatan pengetahun peserta berkaitan dengan pembuatan detergen sebesar 66,8\% (15,7\% menjadi 82,5\%). Selain itu bahwa kelompok mitra juga sudah bisa membuat produk detergen dengan kemasan isi ulang $1000 \mathrm{~mL}, 2 \mathrm{~L}$ dan $5 \mathrm{~L}$.
\end{abstract}

Kata kunci - Detergen, Fajar Baru, Home industri

\section{Pendahuluan}

Desa Fajar Baru merupakan salah satu Desa yang berada di Kecamatan Jati Agung Lampung Selatan. Visi desa Fajar Baru yaitu Membangun Kebersamaan Masyarakat Menuju Kemandirian, yang dituangkan dalam bentuk misinya, yaitu bersama masyarakat mewujudkan desa Fajar Baru yang sehat dan mandiri. Salah satu bentuk kesejahteraan dan kemandirian yang diusahakan adalah tumbuh kembangnya beberapa kelompok kegiatan usaha yang terbingkai dalam kegiatan Home Industri (industri rumah tangga) (Pemerintahan Desa Fajar Baru, 2018).

Desa Fajar Baru berbatasan dengan 1) Sebelah Utara: Desa Karang Anyar dan Karang Sari Kecamatan Jati Agung, 2) Sebelah selatan: Kelurahan Labuhan Dalam Kec. Tanjung
Senang Bandar Lampung, 3) Sebelah Barat: Desa Sidosari Kecamatan Natar dan Kelurahan Rajabasa Jaya Bandar Lampung Lampung dan 4) Sebelah Timur: Desa Jati Mulyo Kec. Jati Agung dan Kel. Tanjung Senang dan Kelurahan Way Kandis Kec. Tanjung Senang Bandar Lampung.

Pusat bisnis, baik pasar tradisional maupun plaza mall atau mini market, warung dan kuliner malam yang berada di lingkaran Desa Fajar Baru merupakan tempat yang diorientasikan untuk memperoleh pemasaran dan keuntungan secara ekonomis. Perubahan kondisi atau kebijakan dalam bidang lain akan selalu mempengaruhi kondisi bisnis yang ada. Kenyataan menunjukkan bahwa faktor yang menciptakan lingkungan bisnis kondusif sangatlah kompleks, saling ketergantungan, pengaruh mempengaruhi antar berbagai faktor 
sehingga sangat multi dimensi. Oleh karena itu pemerintahan desa Fajar Baru secara intens dan terus menerus selalu melakukan dialog, berinteraksi dengan seluruh kalangan dan lapisan masyarakat untuk membangun dan menciptakan lingkungan bisnis yang kondusif bagi semua pelaku bisnis tanpa diskriminatif.

Pembuatan produk loundry, seperti detergen cair. merupakan salah satu produk yang berpotensi dijadikan sebagai kegiatan Home Industri (Kiswandono dan Nurhasanah, 2017). Detergen adalah campuran berbagai bahan, yang digunakan untuk membantu pembersihan dan terbuat dari bahan-bahan turunan minyak bumi. Dibanding dengan sabun, detergen mempunyai keunggulan antara lain mempunyai daya cuci yang lebih baik serta tidak terpengaruh oleh kesadahan air. Pada umumnya, deterjen mengandung bahan-bahan berikut:

1. Surfaktan (surface active agent) merupakan zat aktif permukaan yang mempunyai ujung berbeda yaitu hydrophile (suka air) dan hydrophobe (suka lemak). Bahan aktif ini berfungsi menurunkan tegangan permukaan air sehingga dapat melepaskan kotoran yang menempel pada permukaan bahan. Ada empat kategori surfaktan yaitu:

a. Anionik (Alkil Benzen Sulfonat, Linier Alkil

Benzen Sulfonat (LAS), Alpa Olein Sulfonat (AOS).

b. Kationik (Garam Ammonium)

c. Non ionik (Nonil fenol polietoksil)

d. Ampoterik (Asil Etiilendiamin

2. Builder (Permbentuk) berfungsi meningkatkan efisiensi pencuci dari surfaktan dengan cara menon-aktifkan mineral penyebab kesadahan air. Contohnya

a. Pospat : Sodium Tri Poli Pospat (STPP)

b. Asetat : - Nitril Tri Asetat (NTA), Etilen Diamin Tetra Asetat (EDTA).

c. Silikat : Zeolit

d. Sitrat : Asam sitrat

3. Filler (pengisi) adalah bahan tambahan deterjen yang tidak mempunyai kemampuan meningkatkan daya cuci, tetapi menambah kuantitas. Contoh : Sodium sulfat

4. Zat tambahan (aditif) adalah bahan suplemen / tambahan untuk membuat produk lebih menarik, misalnya pewangi, pelarut, pemutih, pewarna dst, tidak berhubungan langsung dengan daya cuci detergen. Zat aditiv ditambahkan lebih untuk maksud komersialisasi produk. Contoh : Enzim, Borak, Sodium klorida, Carboxy Metil selulosa (CMC).

(http://www.usahalaundry.co.id/2018/10/08/peng ertian-detergen-dan-manfaatnya-serta-mencucitanpa-detergen/)

Hasil pemantauan Tim Pengabdian Kepada Masyarakat di lapangan, sampai saat ini kelompok mitra belum mengetahui peluang bisnis home industry sehingga, akses yang strategis khususnya kedekatannya dengan lembaga pendidikan dan pusat bisnis, yaitu pasar tradisional, minimarket dan kuliner malam. Kemudian, kedekatan dengan lembaga pendidikan SLTA, PTN maupun PTS seperti Universitas Lampung, UIN Bandar Lampung, Universitas Bandar Lampung (UBL) belum terlihat dan terpikirkan. Padahal ini memberikan peluang kepada masyarakat Desa Fajar Baru untuk meningkatkan wirusaha, yakni menjadi produsen dan penyalur, pedagang, ataupun pusat grosir. Disisi lain, kelompok mitra merupakan kelompok yang aktif dalam mengembangkan diri dan membina anggota-anggotanya. Keinginan untuk meningkatkan kesejahteraan terhalangi karena kurangnya pengetahuan dalam dalam hal ide dan keterbatasan melihat peluang bisnis. Oleh karena itu diperlukan pendampingan terhadap kegiatan program kerja mitra, dalam hal ini kelompok PKK.

Tujuan kegiatan pengabdian ini adalah 1) Mendampingi dan membantu mitra dalam upaya pembuatan sabun cair cuci baju atau detergen cair. Dan 2) Meningkatkan pengetahuan, keterampilan dan keahlian mitra dalam hal pembuatan Sabun cair cuci baju atau detergen cair.

\section{METODE KEGIATAN}

Kegiatan pengabdian kepada masyarakat dalam bentuk pendampingan ini dilakukan dalam beberapa tahap seperti juga yang telah dilakukan oleh Kiswandono dkk (2016). Tahapan tersebut diantaranya adalah:

\section{Tahap Sosialisasi Program}

Pada awal kegiatan, Tim pelaksana Pengabdian mensosialisasikan program kepada Kelompok mitra yang juga dihadiri Ketua Dusun, Kepala Desa Fajar Baru dan Tim PKK. Sosialisasi program ini dilakukan melalui metode pendekatan dalam rangka untuk mengubah mainset yang selama ini menjadi beban biaya tanpa hasil menjadi beban biaya yang memberikan kontribusi keuntungan. Mainset kelompok mitra harus diubah menjadi jiwa wirausaha, kreatif dan inovatif. Sehingga diharapkan dengan mainset yang baru dapat mendatangkan keuntungan.

\section{Tahap Pelaksanaan}

\section{a. Tahap Persiapan}

Tahap ini meliputi koordinasi Tim Pengabdian Unila dengan aparat setempat, baik dari mulai izin, penyusunan jadwal kegiatan dan juga persiapan bahan-bahan serta alat yang dibutuhkan didalam pelaksanaan kegiatan (Gambar 1a). 


\section{b. Tahap Pelaksanaan}

Tahap ini terdiri dari:

1). Penyuluhan dan Pelatihan kepada kelompok mitra tentang cara membuat detergen (Gambar 1b)

2). Workshop melalui demonstrasi serta bimbingan langsung kepada kelompok mitra dengan metode FGD (Focus Group Discussion), mengenai pembuatan produk (Gambar 1c).

\section{c. Tahap Evaluasi :}

Evaluasi dilakukan pada beberapa tahap dari kegiatan, yaitu: tahap pertama pada awal kegiatan, selanjutnya tahap kegiatan sedang berlangsung dan tahap akhir. Evaluasi dilakukan pada pelaksanaan program kegiatan meliputi materi penyuluhan dan pelatihan, teknologi yang diterapkan untuk produksi pembuatan detergen serta teknis pengemasan dan pemasaran (Gambar 1d)

\section{d. Tahap Pemantauan :}

Tahap pemantauan dilakukan setelah satu bulan kegiatan pengabdian untuk melihat keberlangsungan produksi pembuatan detergen serta pengelolaan dan pemasaran yang dilakukan mitra sebagai tindak lanjut dan keberlangsungan program kegiatan.

\section{Hasil dan Pembahasan}

Detergen adalah salah satu produk yang telah banyak dipakai. Produk sabun cair yang beredar dan terdiri dari berbagai macam macam bahan, bergantung pada fungsinya. SNI 06-4075 (1996) menjelaskan tentang beberapa bahan yang digunakan untuk mencuci pakaian serta alat dapur tanpa menimbulkan iritasi pada kulit, dibagi menjadi dua jenis yaitu : jenis $P$ untuk pakaian dan jenis D untuk alat dapur.

Hasil kegiatan pengabdian kepada masyarakat dengan mitra Tim PKK Desa Fajar Baru ini dapat diketahui berdasarkan hasil evaluasi yang telah dilaksanakan melalui pre test dan post test. Evaluasi kegiatan dilakukan dengan pengukuran terhadap pencapaian tujuan instruksional khusus (TIK) dari kegiatan yang dilaksanakan dengan parameter pengukuran menggunakan pre test dan post test untuk mengetahui hal-hal berikut: (a) Pengetahuan umum peserta tentang pemasaran detergen (b) Pengetahuan peserta tentang fungsi detergen, (c) Pengetahuan peserta tentang bahan baku untuk pembuatan detergen skala menengah, (d) Pengetahuan peserta tentang pembukuan dalam penerimaan dan pengeluaran arus keuangan penjualan Pembuatan merk dagang home industry

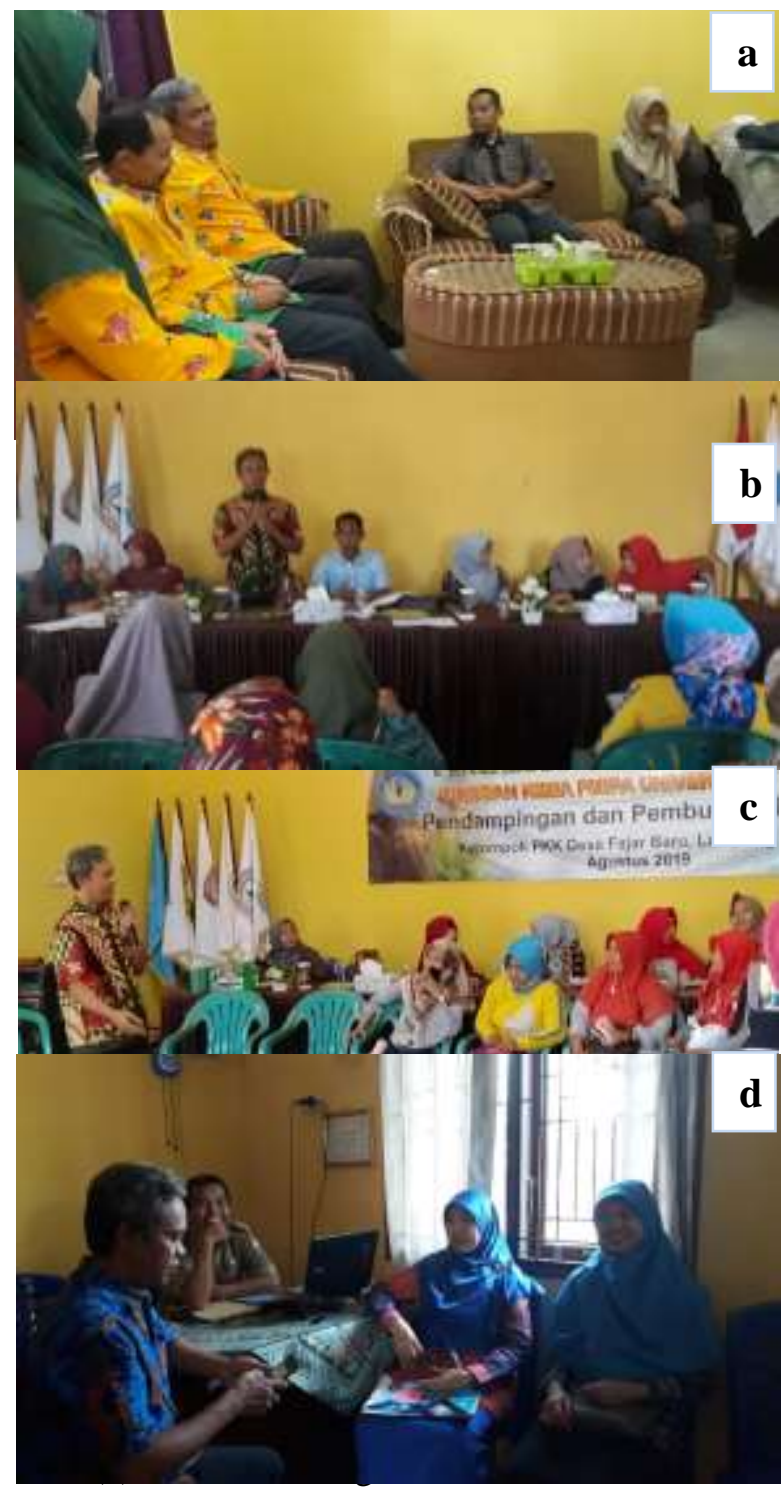

Kasi Kesejahteraan Desa Fajar Baru, (b) Sosialisasi pembuatan detergen, (c) FGD (Focus Group Discussion) pembuatan detergen (d) Evaluasi bersama bapak Sekdes Fajar Baru.

Kegiatan pengabdian kepada masyarakat ini didukung oleh besarnya kemauan dan semangat Tim penggerak PKK desa Fajar Baru yang menginginkan wirausaha untuk peningkatan pendapatan bagi masyarakatnya. Besarnya kemauan dan semangat masyarakat untuk peningkatan pengetahuan tentang pembuatan sabun ini dapat dilihat dari peningkatan TIK pada setiap peserta setelah kegiatan pengabdian ini dilaksanakan. Masing-masing TIK menunjukkan kecenderungan terjadi peningkatan dengan prosentase peningkatannya dapat dilihat pada Tabel 1. 
Tabel 1. Perbandingan hasil pencapaian TIK pada pre test dan post test

\begin{tabular}{lllccc}
\hline No & \multicolumn{2}{c}{ Tujuan Instruksional Khusus } & \multicolumn{3}{c}{ Pencapaian TIK (\%) } \\
\cline { 3 - 5 } (TIK) & Pre test & Post test & Peningkatan \\
\hline 1 & $\begin{array}{l}\text { Pengetahuan umum peserta tentang } \\
\text { pemasaran detergen }\end{array}$ & 25.00 & 90.00 & 65 \\
2 & $\begin{array}{l}\text { Pengetahuan peserta } \\
\text { detergen }\end{array}$ & 12.5 & 92.50 & 80 \\
3 & $\begin{array}{l}\text { Pengetahuan peserta tentang bahan baku } \\
\text { untuk pembuatan detergen skala menengah }\end{array}$ & 15.00 & 75.00 & 60 \\
4 & $\begin{array}{l}\text { Pengetahuan peserta tentang pembukuan } \\
\text { dalam penerimaan dan pengeluaran arus }\end{array}$ & & & \\
keuangan penjualan & 16.00 & 85.00 & 69 \\
5 & \begin{tabular}{l} 
Pembuatan merk dagang home industry \\
\multicolumn{3}{c}{ Rata-Rata }
\end{tabular} & 10.00 & 70.00 & 60 \\
\hline
\end{tabular}

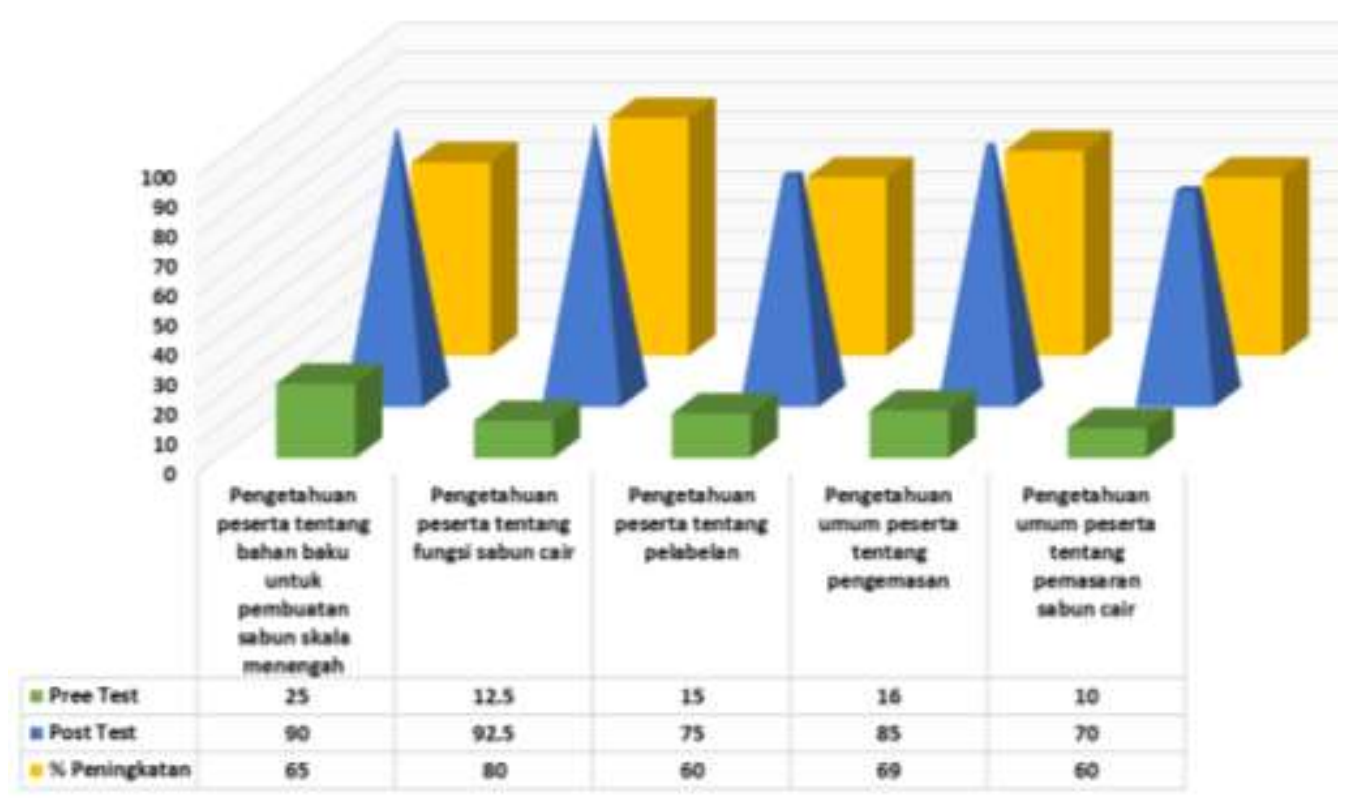

Gambar 2. Perbandingan pencapaian Tujian Intruksional Khusus (TIK) pada peserta pelatihan pembuatan detergen

Pada Tabel 1 dan Gambar 2 dapat dilihat bahwa, masing-masing TIK telah mengalami kenaikan dengan rata-rata sekitar 60 sampai $80 \%$. Pada pengetahuan umum peserta tentang pemasaran sabun cair dan pelabelan atau merk (item 1 dan 4), kenaikan pengetahuannya hanya mencapai $60 \%$, hal ini disebabkan karena peserta pelatihan masih terfokus pada pembuatan produk, sehingga saat pemberian materi pemasaran dan pelabelan para peserta pelatihan kurang begitu memahami. Berbeda dengan item dua, yaitu tentang fungsi dan pembuatan sabun cair atau detergen, kenaikan pengetahunnya mencapai $80 \%$. Hal ini juga dibuktikan, ketika Tim Pengabdian melakukan monitoring dan evaluasi berkaitan dengan cara pembuatan produk detergen, peserta pelatihan sudah dapat membuat detergen tanpa didampingi oleh Tim Pengabdian.
Hal ini menunjukkan bahwa pengetahuan masyarakat tentang "PKM Pendampingan dan Pembuatan Detergen Kelompok PKK Desa Fajar Baru Lampung Selatan telah meningkat secara signifikan sehingga secara keseluruhan tujuan awal dari kegiatan ini telah dicapai dengan memuaskan.

Kemudian, harapan dari pengabdian ini juga diharapkan agar peningkatan pengetahuan ibu-ibu PKK ini nantinya dapat diturunkan ke masyarakat desa Fajar Baru secara umum sehingga dapat bersinergi dalam peningkatan kesejahteraan masyarakat dan pemberantasan pengangguran.

Evaluasi juga dilakukan terhadap kegiatan pengabdian masyarakat dan produk detergen yang telah dibuat yaitu dengan meminta pendapat masyarakat dan para pengguna produk sabun cair 
dalam hal ini Ibu-ibu PKK Desa Fajar Baru terhadap kegiatan pengabdian dan kualitas sabun cair yang dibuat bersama-sama dan diberi label chemlight serta dikemas dalam berbagai variasi kemasan seperti terlihat pada Gambar 3. Evaluasi dilakukan berupa pemberian kuisioner. Salah satu pertanyaan kuisioner adalah "Apakah kegiatan pelatihan "pembuatan sabun cair sebagai produk home industry" sangat berguna?. Hampir semua peserta memilih jawaban sangat setuju

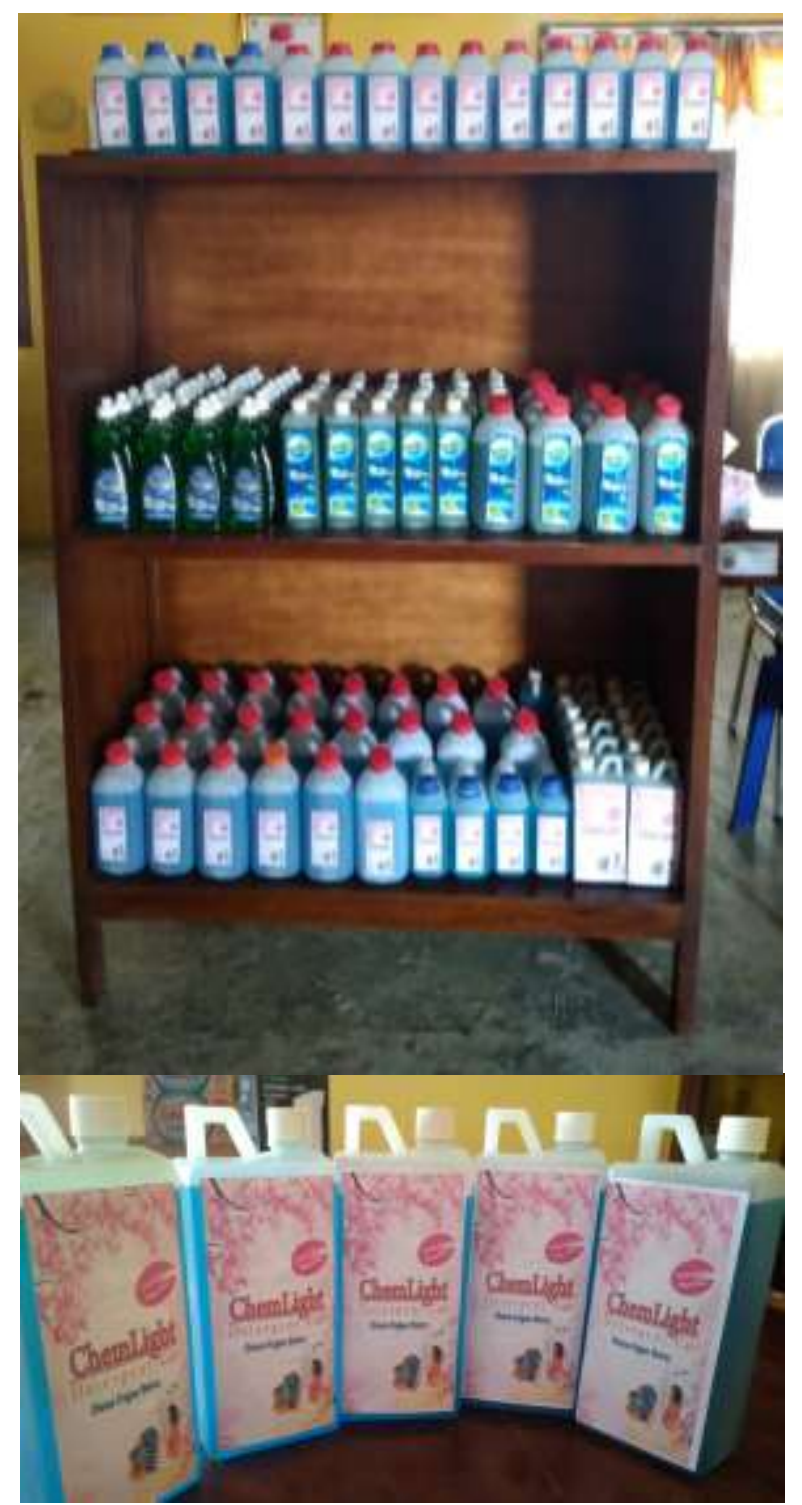

Gambar 3. Beberapa kemasan detergen hasil buatan mitra, kelompok PKK Desa Fajar Baru

Berdasarkan hasil kuisioner tersebut dapat disimpulkan bahwa kegiatan ini sangat berguna bagi masyarakat karena merupakan usaha yang berkelanjutan dan dapat menjadi sumber pendapatan bagi masyarakat khususnya ibu-ibu PKK. Masyarakat sangat mengharapkan diadakan kegiatan pembinaan dan pelatihan untuk produk home industri lain yang yang dapat meningkatkan keterampilan dan pendapatan masyarakat.

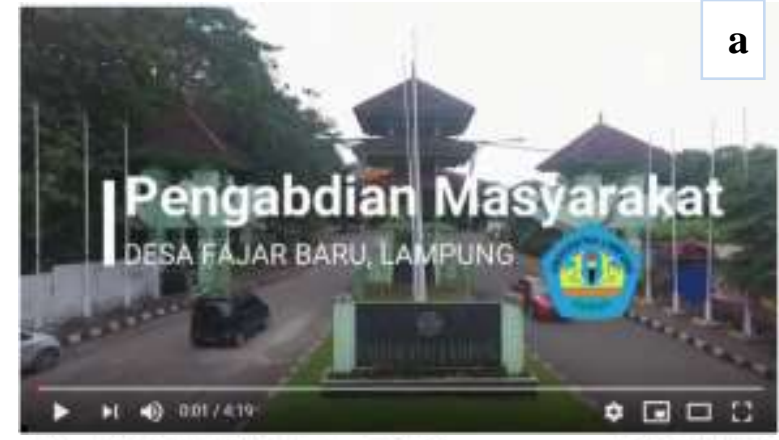

$4 G_{\text {a }} 3 G$, ill $0,3 K / s \$$ 回 $\cdots 12: 42$

$4 G: 34 \%,+6$

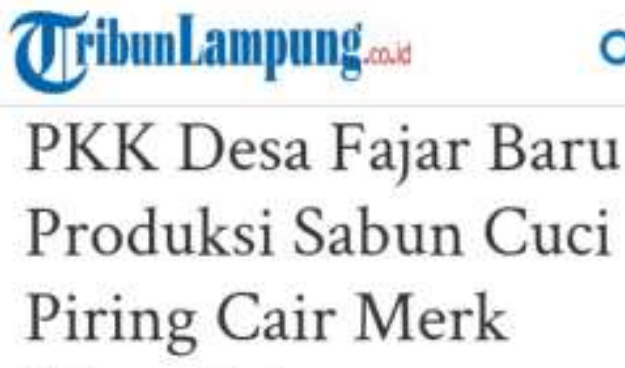

\section{Chemlight}

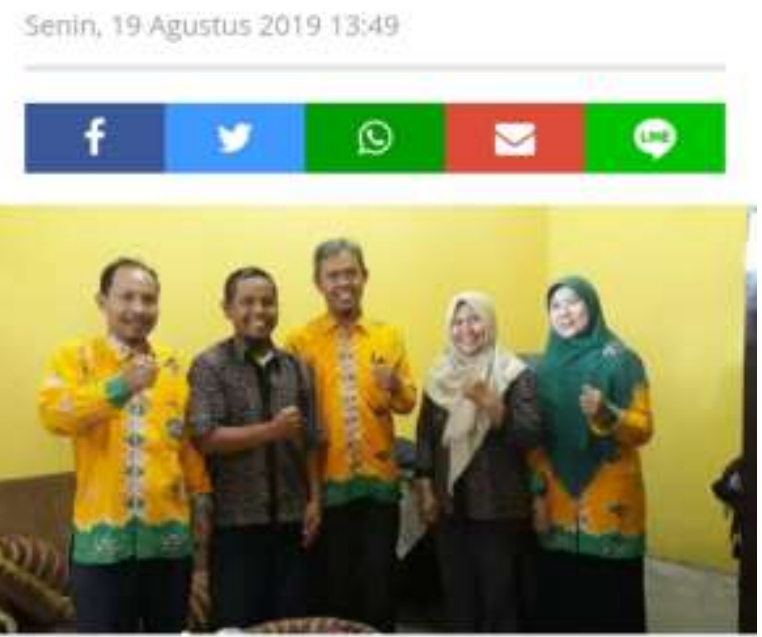

Tribunlampung.co,id/5utis

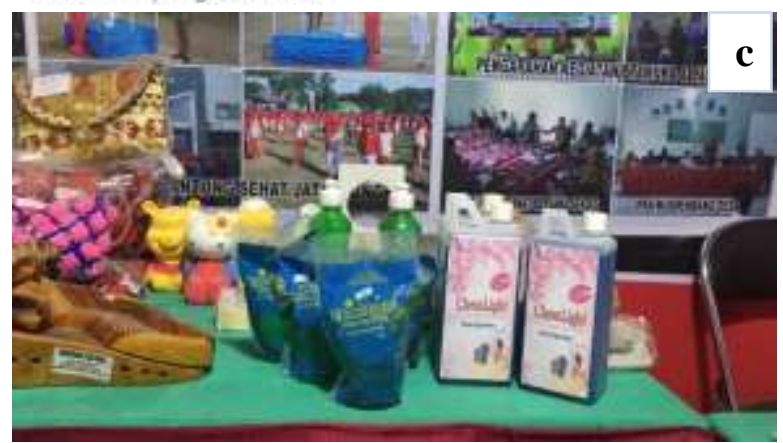

Gambar 4. Luaran pengabdian masyarakat

(a) video kegiatan yuotube,

https://www.youtube.com/watch?v=UUlvMOHJ 2oo\&feature $=$ youtu.be

(b) Lampung Tribun online

https://lampung.tribunnews.com/2019/08/19/pkk

-desa-fajar-baru-produksi-sabun-cuci-piring-cairmerk-chemlight

(c) Pameran di Kota Kabupaten Lampung

Selatan, Kalianda. 
Berdasarkan hasil kuisioner tersebut dapat disimpulkan bahwa kegiatan ini sangat berguna bagi masyarakat karena merupakan usaha yang berkelanjutan dan dapat menjadi sumber pendapatan bagi masyarakat khususnya ibu-ibu PKK. Masyarakat sangat mengharapkan diadakan kegiatan pembinaan dan pelatihan untuk produk home industri lain yang yang dapat meningkatkan keterampilan dan pendapatan masyarakat.

Menurut ibu-ibu PKK Desa Fajar Baru sebagai pengguna produk sabun cair, sabun cair buatan Desa Fajar Baru tidak kalah dengan produk bermerek yang sudah beredar di pasaran.

Sabun cair yang merupakan sabun cuci baju ini sudah menghasilkan kualitas yang baik, jika dilihat dari kemampuannya membersihkan, dimana dapat menghilangkan kotoran dan keringat pada pakaian. Selain itu, keharumannya yang tahan lama dan teksturnya yang stabil setelah sebulan pembuatannya serta baunya yang harum (wangi) menjadikan produk sabun cair ini ingin dikembangkan menjadi produk home industry oleh ibu-ibu PKK Desa Fajar Baru. Kegiatan pengabdian ini selanjutnya dipublikasikan melalui youtube (Gambar 4a), media Tribun online (Gambar 4b) dan pameran di Ibukota Kabupaten Lampung Selatan, Kalianda (Gambar 4c).

\section{Kesimpulan}

Hasil kegiatan yang telah dilaksanakan pada pendampingan pengetahuan ibu-ibu PKK Desa Fajar Baru tentang "PKM pendampingan dan pembuatan detergen kelompok PKK Desa Fajar Baru Lampung Selatan" telah meningkatkan pengetahuan mitra rata-rata $66,8 \%$ (15,7 menjadi 82,5). Berdasarkan kuisioner, hampir semua peserta pelatihan menginginkan agar adanya pendampingan program kerja secara kontinyu pada mitra.

\section{Ucapan Terima Kasih}

Direktorat Riset dan Pengabdian Masyarakat Direktorat Jenderal Penguatan Riset dan Pengembangan Kementrian Riset, Teknologi dan Pendidikan Tinggi (No. 1408/UN26.21 /PM/2019, Tanggal 14 juni 2019), LPPM Universitas Lampung, dan Kepala Desa, Ibu Ketua PKK serta Perangkat Desa Fajar Baru.

\section{Daftar Pustaka}

Badan Standardisasi Nasional, 1996, SNI 064075-1996, Gedung I BPPT, lantai 9 - 14. Jl. M.H Thamrin No. 8 Kebon Sirih Jakarta Pusat 10340 - Indonesia.
Kiswandono, A.A dan Nurhasanah, 2017. Produk Rumah Tangga: Sabun Cair, Detergen, Softener, dan Pemutih (Seri Buku Kimia Dalam Kehidupan). Penerbit Aura. Bandar Lampung.

Kiswandono A.A., Juliasih, N.R.G., Nurhasanah. 2016. Laporan Pengabdian Kepada Masyarakat "Pendampingan Dan Pembuatan Sabun Cair Pencuci Piring Bagi Kelompok Ibu-Ibu PKK Desa Fajar Baru Kecamatan Jati Agung Lampung Selatan, Jurusan Kimia FMIPA Universitas Lampung.

Pemerintahan Desa Fajar Baru, 2016, Profil Desa Fajar Baru.

Anonim, 2019, Detergen dan manfaatnya, http://www.usahalaundry.co.id/2018/10/0 8/pengertian-detergen-dan-manfaatnyaserta-mencuci-tanpa-detergen/)

Video kegiatan pengabdian masyarakat, 2019, Pengabdian Masyarakat Desa Fajar Baru, https://www.youtube.com/watch?v=UUl vMOHJ20o\&feature $=$ youtu.be

Sulis setia markhamah, Tribun online, 2019, PKK Desa Fajar Baru Produksi Sabun Cuci Piring Cair Merk Chemlight, https://lampung.tribunnews.com/2019/08 /19/pkk-desa-fajar-baru-produksi-sabuncuci-piring-cair-merk-chemlight 